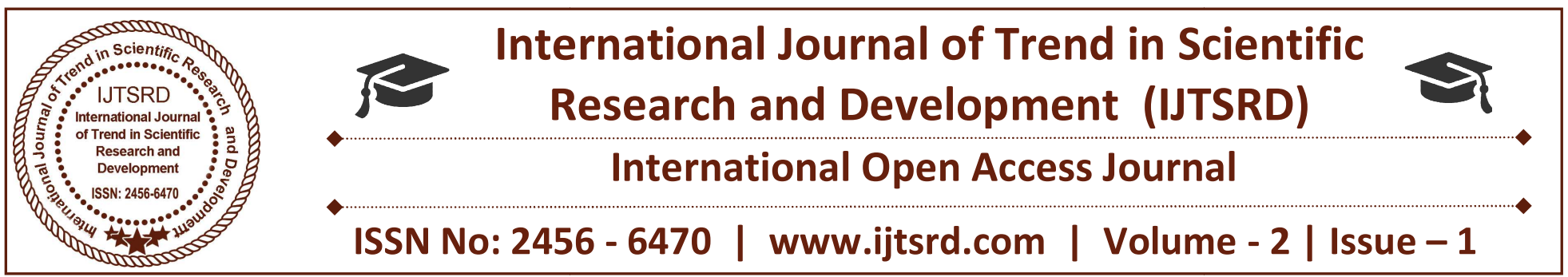

\title{
Group Approach as a Tool for Women Empowerment - A Study
}

\author{
Puspita Das \\ Associate Professor, College of Home Science, \\ CAU, Tura, Meghalaya
}

\author{
Ayuta Mohanty \\ Guest Faculty in English, Rajdhani College, \\ Bhubaneswar, Odisha
}

\section{ABSTRACT}

Women in a patriarchal society like India have been suffering since ancient times. The prevailing gender inequality acts as barriers in the path of women empowerment. In rural areas, especially, the condition is at its worst. The women in rural areas are suppressed by three forces. The first one is, of course, their gender- they are women. The second factor is poverty which is followed by the third factor, i.e. social backwardness. These three forces combine together and play havoc in the lives of women living in rural parts of India. Without empowering women, it is impossible for a nation to develop. To achieve empowerment in its complete sense, development should be reflected at all levels. Without improving the conditions of these rural women, it is impossible for us to achieve woman empowerment. Self-Help Groups play a major role in helping these women to live a life of dignity and economic independence. These groups influence social, economic, and mental powers of women to a great extent. This group approach can be instrumental in bringing change in the lives of the women helping the country in achieving women empowerment. This paper focuses on the role that these groups play to help the rural women to achieve a means of sustainable livelihood and to provide better future for their families, in particular, and the nation, in general. This paper also analyses how this group approach is essential for achieving our goal of women empowerment in our country.

Keywords: SHGs, women, empowerment, economic, change
We use the term women empowerment every now and then, but we rarely stop to wonder what exactly the term implies. "It is both a process and the result of the process. It is transformation of the structures or institutions that reinforces and perpetuates gender discrimination. It is a process that enables women to gain access to and control of material as well as information resources" (Suguna, 2006). Women empowerment is an essential factor in the path of development. For any nation to develop, it needs is essential to empower its women. Empowerment involves people in an active role, not only in decision making, but also an understanding of the factors that shape a situation, and the nature of oppression itself (Murthy 2001). Women in India have always faced various forms of injustice due to prevailing gender inequality. In the rural areas, the condition of women is even worse. Women in many parts of rural India carry the burden of both handling the household chores and working outside to earn something for their family. These women get exploited at both the places. In the domestic sphere, they face various issues like domestic violence, various forms of tortures from in-laws, pressures to beget a male heir, maternal mortality and negative effects of repeated pregnancies on the health of the mother. They always play passive role in decision making. Sometimes they play suggestive roles but not decisive role. While working in fields or factories, they are given an equal share of work with men but as far as the wages are concerned women are paid less than men. Their health conditions never get required attention and it worsens their conditions. In various other parts of rural India, women are not allowed to work outside. The villagers follow the ideal patriarchal household model where 
the men act as the breadwinner of the family and women takes care of the family and household. In both the cases, productivity gap based on gender and women's economic position keeps on deteriorating. The major areas where gender inequality can be seen are education, health and employment.

"Women's economic contributions are an integral part of rural India, yet most remain invisible, unrecognized and undervalued. This problem stems from two factors: first the limiting definition of economic activities, and second, social hierarchy and the power structure, which assign status and values to activities" (Dalal, 1997, 203). As these women of rural areas are denied proper education, they are forced to remain dependent on men for economic support. Even if they try to search outside for employment, they get trapped in jobs where they are exploited for very little wages.

Self-Help Groups (SHGs), as the name suggests, is a small group of people from similar socio-economic status grouping together to resolve their mutual problems through self-help. "The concept of SHG serves the principle "by women, of the women and for the women". SHGs help in creating a platform for sharing of experiences, collective knowledge, building problem, solving and resource mobile satisfaction and other institutions. In SHGs the autonomy of the women groups is never undermined and all decision making is entirely in their hands. This group helps women to build confidence in themselves as decision makers, planners and to work collectively in a democratic manner" (Suguna, 2006).

There are various reasons because of which rural women prefer to join or form these groups. Firstly, it gives them economic security. The SHG activities help them to earn something for their livelihood and it also encourages them to save some amount in the group fund for emergencies of any member. As they are able to earn their livelihood, they don't have to depend on the men. It gives them a sense of economic independence. For any enterprise they do not have anything to fulfil the collateral obligation and lose their access to credit and capital. Formation of Group helps them to get loans and helps to become entrepreneur without mortgage as per RBI Guidelines. Moreover, they are able to help their family by contributing a part of their income for household expenses. Secondly, they can easily get loans for starting any new business from banks and NGOs. Because of their dealings with the bank, they get a better idea of different banking operations and credit managements. Thirdly, they like the cooperative atmosphere while working together. It enhances their social participation, their ability to interact with others and express their ideas which boosts their confidence and personality. It also sharpens their leadership qualities. More over by joining these groups, they are trying to redefine various social and religious boundaries. Next, it also inculcates in them the habit of saving. They learn how to save some amount for future emergencies or endeavors. These groups not only influence their economic and social realms but also enhance their personal realms. By dealing in various activities in a democratic manner, their levels of confidence, self-esteem and self-realization increases. Their ability to make decisions on their own develops to a great extent. Their communication skills are also improved. Group approach helps the women to solve many gender issues, they share with each other and care for each other, learn how to raise voices against injustice which individually they will not dare to do. "As a group-oriented model, SHGs in India is a mechanism for women's development to bring in individual and collective empowerment through improvement in both 'condition' and 'position' of women. SHGs are platforms and forums to mobilize women to protest against domestic violence, rising prices, legal discrimination, crime against women, child marriage etc. In this way, it aims to empower women with various forms of power" (Mishra, 88).

Several factors and strategies have been provided by the SHGs that have made a positive contribution in empowering women. These groups are supportive and sources of timely advice for balancing family and business responsibilities, leadership, experience in decision making and discussions on social issues. As a result, the numbers of SHGs have been increasing day by day. Women who comprise half of human resources have been identified as key agents of sustainable development and women equality is as central to a more holistic approach towards stabilizing new patterns and process of developments (Jha, 2009). If we compare the rural women with the urban women, we find a large gap between them. This is due to lack of proper education, lack of opportunities and lack of resources in rural areas. And this group approach helps them to overcome these limitations and they use it as an opportunity to enrich their skills, equip themselves with knowledge, to improve their work capacity and for living a better life with 
improved socio-economic status. Thus this group approach plays very important role in achieving woman empowerment, especially in the rural areas. If utilized properly this approach can enhance the capabilities of women and help in achieving the goal of women empowerment in its true sense. "The contribution of women and their role in the family as well as in the economic development and social transformation are pivotal. Now-a-days economic development is one of the factors that have changed the entire scenario of social and cultural environment within the country especially for the women. The rural women are engaged in small scale entrepreneurship programme with the help of SHGs and through these that they are economically empowered and attaining status in family and community. Rural women play a vital role in farm and home system. She contributes substantially in the physical aspect of farming, livestock management, post-harvest and allied activities. Her direct and indirect contribution at the farm and home level along with livestock management operation has not only help to save their assets but also led to increase the family income. She performs various farm, livestock, post-harvest and allied activities and possesses skills and indigenous knowledge in these areas. The women were empowering themselves technically to cope with the changing times and productively using their free time and existing skills for setting and sustaining enterprises. They were engaged in starting individual or collective in- come generation program me with the help of self-help-group. This will not only generate income for them but also improve the decisionmaking capabilities that led to overall empowerment" (Mishra, 88).

\section{REFERENCES:}

1) Dalal, Meenakshi N. "Social Technology and Gender Inequality in Rural India". Economic Dimensions of Gender Inequality: A Global Perspective.USA: Praeger Publishers. 1997. Print.

2) Jha, Birendra K. Empowerment of Rural Women in India. New Delhi: Kanishka Publishers.2009.Print.

3) Mishra, Nirupama. "Empowering Women through Self Help Groups (SHGs) In Odisha - An Empirical Analysis". International Journal of Novel Research in Humanity and Social Sciences. Vol-3, Issue 3 (2015): 88.

4) Murthy, RK. Building Women's Capacities: Interventions in Gender Transformations. New Delhi: Sage Publications.2001.Print.

5) Suguna, B. Empowerment of Rural Women Through Self Help Groups. New Delhi: Discovery Publishing House.2006.Print. 